\title{
Pemaknaan cerita rakyat Brayut: Dari ideologi agraris hingga kapitalis
}

\author{
I Wayan Budi Utama \\ Universita Hindu Indonesia Denpasar \\ Email: budi_utama2001@yahoo.com
}

\begin{abstract}
Abstrak
Brayut adalah salah satu cerita rakyat Bali yang mengisahkan tentang kehidupan keluarga petani yang memiliki banyak anak. Latar ceritanya tentang pelaksanaan perayaan Galungan. Seiring waktu cerita rakyat ini tetap berkembang hingga saat ini karena mengalami proses konstruksi, dekonstruksi, dan rekonstruksi ideologi yang disampaikan. Tulisan ini membahas ideologi yang berkembang pada tokoh Brayut ini mulai era tradisional, modern, dan postmodern saat ini. Pengumpulan data dilakukan dengan teknik observasi, wawancara dan studi dokumen. Untuk membantu menganalisis permasalahannya digunakan teori ideology oleh Thomson dan dibantu teori-teori agama. Analisis data dilakukan dengan deskriptif interpretatif. Dari hasil analisis yang dilakukan difahami bahwa cerita rakyat ini selalu mengalami penafsiran ulang dari era tradisional/ agraris hingga era postmo saat ini. Dengan demikian, cerita Brayut dapat bertahan sampai sekarang.
\end{abstract}

Kata kunci: cerita rakyat Brayut, keluarga berencana, interpretasi, ideologi,

\begin{abstract}
Brayut is one of Balinese folktale that tells about a farmer's family life with many children. The setting relates to the celebration of Galungan day. By the time being, this story always exists and develops until today. This folktale has been undergoing certain process of construction, deconstruction, and reconstruction of ideology. This paper concerns the ideology implied by the character of Brayut since the traditional until this postmodern era. The research data was collected through the observation, interview, and document study techniques. The analysis was based on the theory of ideology by Thomson supported by the theories of religion. The descriptive-interpretative method was applied
\end{abstract}


to analyze the data. Based on the analysis the results show that this folklore of Brayut has been always reinterpreted since the traditional/agriculture era until this postmodern era. Therefore, the existence of this story may be everlasting until today.

Key words: Brayut folktale, family planning, interpretation, ideology

\section{Latar Belakang}

Salah satu cerita rakyat Bali yang sangat terkenal dan tetap Sbertahan hingga saat ini adalah tentang keluarga Brayut. Masa-masa sebelum Orde Baru, legenda ini sangat akrab dengan masyarakat Bali dan terdokumentasinya dalam bentuk gaguritan Brayut. Dalam sistem religi masyarakat Hindu di Bali, Brayut juga dikenal sebagai media pemujaan untuk memohon keturunan bagi keluarga yang telah lama menikah namun belum dikarunia anak. Hasil penelitian yang dilakukan oleh Soekartiningsih (2000:30) menunjukkan bahwa Brayut dikenal sebagai simbol kesuburan. Sementara itu penelitian yang dilakukan oleh Worsley (2015:1) terhadap tokoh Brayut dalam seni lukis gaya Kamasan menunjukkan bahwa tradisi menuangkan Brayut dalam bentuk lukisan terjadi pada sekitar akhir abad ke sembilan belas dan atau awal abad ke dua puluh. Pada era ini legenda tentang Brayut menyebar luas pada masyarakat Bali, terindikasi dari persebaran naskah gaguritan Brayut yang ditemukannya. Beberapa tempat memberikan petunjuk terhadap eksistensi keluarga Brayut sebagai simbol kesuburan masih bertahan hingga saat ini seperti di pura Silayukti Gianyar, Pura Pengadangan Denpasar, Pura di Candi Dasa Karangasem, dan Pura Dalem Desa Junjungan Ubud, Gianyar.

Pada masa era Orde Baru, posisi Brayut menjadi terpinggirkan akibat adanya program Keluarga Berencana. Brayut telah diposisikan sebagai keluarga yang tidak patut diteladani karena keluarga Brayut memiliki banyak anak. Hal ini berlawanan dengan wacana yang dikembangkan oleh penguasa saat itu dalam membentuk keluarga kecil bahagia dan sejahtera, dua anak lakilaki atau perempuan sama saja.

Saat ini setelah era Orde Baru berlalu yang menurut pandangan para pengamat bahwa era ini adalah era pascamodern, legenda 
Brayut kini kembali menjadi bahan inspirasi bagi para seniman khususnya seniman patung untuk memproduksi patung-patung Brayut dengan berbagai gaya dan langgamnya.

Dengan demikian dapat dikatakan bahwa cerita rakyat Brayut ini tetap eksis dalam masyarakat Hindu di Bali mulai dari era tradisional hingga pascamodern saat ini. Tulisan ini mencoba menggali ideologi dibalik cerita rakyat dimaksud berdasarkan interpretatif dan dipaparkan secara naratif. Untuk mengumpulkan data yang dibutuhkan dalam penulisan ini dilakukan dengan teknik observasi, wawancara dan studi dokumen.

\section{Sinopsis}

Cerita rakyat yang bercerita tentang keluarga Brayut ditulis dalam bentuk gaguritan dengan pupuh Tikus Kapating (Sinom) koleksi Pusat Dokumentasi Kebudayaan Bali, koleksi Nomor IVd. 1399/14. Diceritakan keluarga Brayut adalah keluarga petani penganut Budha, tetapi dalam gaguritan ini diceritakan bahwa mereka merayakan hari raya Galungan. Pada saat perayaan Galungan dia membuat berbagai bentuk makanan olahan daging babi untuk dipersembahkan sebagai sesaji. Sementara istrinya masih tertidur lelap karena kelelahan mengurusi anaknya yang berjumlah 18 termasuk yang masih dalam kandungan. Berbagai polah anakanaknya yang membuat si ibu menjadi sangat terkuras tenaganya sehingga tidak sempat membantu suaminya menyiapkan upacara.

Ketika terbangun dari tidurnya si ibu langsung ke dapur untuk makan berbagaijenis makanan yang tadinya sudah dipersembahkan sebagai sesaji. Berbagai jenis olahan daging dimakannya dengan lahap, tanpa mempedulikan anak-anaknya yang menangis. Tibatiba suaminya Brayut datang dan memarahinya. Terjadi perdebatan antara keduanya terkait banyaknya anak-anak yang lahir. Si suami menyalahkan istrinya, sedangkan si istri membela diri dengan menyatakan bahwa anak-anak mereka lahir akibat si suami tidak mampu mengendalikan nafsu birahinya. Setiap ada kesempatan si suami selalu mengajak istrinya untuk melakukan hubungan seks.

Selanjutnya dikisahkan Brayut mulai belajar ilmu ketuhanan pada seorang Guru bijak bernama Pangeran Jembong yang sangat menguasai ilmu tentang ajaran agama Budha. Setelah mendapatkan banyak pelajaran Pan Brayut kemudian melakukan tapa semadi di pohon kepuh besar yang bagian bawahnya berlubang di sebuah 
kuburan yang angker. Atas karunia Tuhan akhirnya ilmu Pan Brayut disempurnakan.

Ringkas cerita setelah anak-anaknya dewasa dan menikah, Pan Brayut dan Men Brayut akhirnya memutuskan untuk meninggalkan anak-menantunya untuk pergi mengasingkan diri dengan membuat sebuah pasraman. Sebuah pesta besar dibuat oleh anak-anaknya, berbagai makanan olahan daging disajikan dalam pesta tersebut, dan tak ketinggalan berbagai jenis minuman berupa tuak, arak, berem. Setelah pesta usai Pan Brayut dan istri diantar anak-anak dan warga menuju tempat yang telah dipersiapkan untuk melanjutkan hidupnya sebagai penekun kerohanian.

\section{Ideologi dalam Legenda Brayut dari Masa ke Masa}

Menurut Thompson (2000:16) konsep ideologi dapat digunakan untuk merujuk cara-cara bagaimana makna digunakan dalam kekuasaan yang secara sistematis bersifat asimetris atau dengan kata lain bersifat relasi dominasi. Dengan kata lain dapat dikatakan bahwa ideologi adalah makna yang digunakan untuk kekuasaan. Dengan demikian studi tentang ideologi mensyaratkan untuk menginvestigasi cara-cara bagaimana makna dikonstruksi dan disampaikan melalui bentuk-bentuk simbol dalam jenisnya yang bervariasi. Ia juga mengisyaratkan untuk menginvestigasi konteks sosial tempat diterapkan dan disebarkan dan diterapkannya bentuk-bentuk; menuntut kita mempertanyakan apakah, demikian juga bagaimana, makna yang dimobilisir bentuk-bentuk simbol digunakan dalam konteks tertentu, untuk membangun dan mempertahankan relasi dominasi.

Bertitik tolak dari pandangan Thompson di atas kiranya dapat diungkapkan ideologi yang terkandung dalam legenda keluarga Brayut dari masa tradisional hingga masa pascamodern saat ini dapat dipaparkan sebagai berikut.

Pada era tradisional, simbol-simbol kesuburan dalam arti luas seperti hasil pertanian yang melimpah dengan jumlah keluarga yang besar sebagai sumber daya dalam pengerjaan lahan pertanian menjadi penting. Hadirkan Brayut sebagai simbol kesuburan pada era tradisional pertanian berkaitan erat dengan sistem religi yang berkembang pada masa itu. Simbol-simbol keagamaan menjadi sangat penting artinya sebagai ideologi untuk mempertahankan relasi dominasi. 
Agama mengaktualisasi dalam kehidupan para pemeluknya maka keberagamaan terintegrasi ke dalam sistem nilai sosial budaya, dan wujud kebudayaan fisik yang kemudian bersentuhan melalui proses sosial dengan elemen-elemen sosial budaya lainnya. Secara sosiologis agama dalam realitas kehidupan akan bersentuhan pula dengan pemenuhan kebutuhan hidup manusia, baik yang bersifat fisik-biologis, sosial, ekonomi, dan politik, maupun kebutuhankebutuhan integratif yang menyangkut hal-hal yang sangat penting dalam kehidupan manusia, yaitu keinginan untuk hidup beradab, bermoral, tenteram, dan damai. Dengan demikian dapat dikatakan bahwa keberagamaan itu saling terkait antara hal-hal yang bersifat normatif dengan dimensi kehidupan yang bersifat praksis aktual, baik pada level individual maupun kolektif. Agama dalam hal ini memiliki posisi sentral terutama berkaitan dengan pembentukan nilai-nilai dan norma-norma sosial yang dalam praktiknya tidak jarang ditemukan saling berbenturan antara yang satu dengan yang lain. Agama diharapkan mampu menjadi pendamai dalam paradoksal kehidupan nilai dan norma dalam tataran yang paling sublim karena selain agama manusia tidak lagi memiliki keyakinan tempat menyandarkan nilai kehidupan yang terakhir.

Dengan demikian keberagamaan bukanlah keterpisahan secara total antara sistem gagasan berupa ide-ide dan praktiknya dalam dunia empiris berupa pengalaman-pengalaman. Melainkan antara keduanya merupakan kesatuan ide dan praktik dalam bentuk pengabdian diri secara terus-menerus yang mengantarkan penganutnya kepada ketenangan dan kedamaian (hati).

Terkait dengan uraian di atas Brayut menjadi gambaran tentang struktur tindakan sosial dan kebudayaan masyarakat Bali pada zamannya. Dapat pula ditafsirkan bahwa keberagamaan masyarakat lokal pada waktu itu sudah tinggi sehingga mampu melakukan lokalisasi ajaran-ajaran Hindu dan Budha sesuai dengan lokal jenius yang dimiliki masyarakat (Utama, 2015:1187). Hasil penelitian di lapangan menunjukkan bahwa tokoh Brayut rupanya menjadi simbol baik bagi penganut paham Buddhis, penganut Siwais dan sistem kepercayaan lokal. Indikasi ke arah ini terlihat pada hasil wawancara dengan I Ketut Sumbu (53 tahun) dari Desa Samuan, Candi Dasa Karangasem. 
"Tokoh puniki wenten sane maosan Dewi Hariti, Dewi Sri, wenten taler sane maosang Men Brayut"

\section{Artinya :}

Ada yang menyebut tokoh ini sebagai Dewi Hariti, Dewi Sri, da nada juga yang menyebutnya Men Brayut “

Tempat pemujaan Brayut yang terletak di Desa Samuan, Candi Dasa Karangasem kini sedang dipugar. Tinggalan yang terdapat di Pura ini berbentuk arca seorang perempuan yang sedang dikerubuti oleh anak-anak. Seperti penuturan I Ketut Sumbu, sesuai dengan nama desa tersebut yaitu Samuan, diperkirakan di zaman dahulu daerah ini merupakan pasamuan berbagai konsep keagamaan seperti ajaran Siwa, Budha dan sistem kepercayaan lokal.

Pemikiran ini dilandasi oleh berbagai pertimbanganpertimbangan sebagai berikut. Tokoh perempuan dengan banyak anak dalam mitologi Buddha dikenal dengan sebutan Dewi Hariti. Pada mulanya dia adalah seorang yaksa yang suka makan daging manusia. Namun setelah mendapatkan pencerahan dari ajaran Buddha, Dewi Hariti berubah menjadi Dewi yang sangat sayang kepada anak-anak. Arca sejenis juga ditemukan di Pura Goa Gajah Gianyar.

Di sisi lainnya Brayut di Pura Candi Dasa ini juga dipuja sebagai Dewi Sri, Dewi pemberi kemakmuran bagi masyarakat Hindu di wilayah tersebut. Dewi Sri juga diyakini dapat menghilangkan segala "mala" atau kekotoran dalam diri manusia. Masyarakat sering memohon tirta panglukatan di tempat ini dengan cara membersihkan diri di "Yeh Mapalu" yaitu pertemuan antara air tawar dengan air laut yang letaknya di depan Pura.

Masyarakat setempat menyebut arca di Pura ini sebagai Men Brayut, yang diyakini sebagai Dewi penyayang anak-anak. Di tempat ini ada juga yang memohon anak terutama bagi pasangan nikah yang lama belum memperoleh keturunan.

Dengan demikian satu tokoh ini menjadi simbol dari berbagai bagai sistem keyakinan yang berkembang dalam masyarakat. Berdasarkan hasil pengamatan di lokasi penelitian dijumpai reliefrelief yang menggambarkan kondisi dimaksud sebagaimana gambar 1 dan 2 berikut ini. 
Gambar 1. Palinggih Dewi Sri, Dewi Hariti, atau Men Brayut di Desa Candidasa Karangasem (koleksi pribadi).
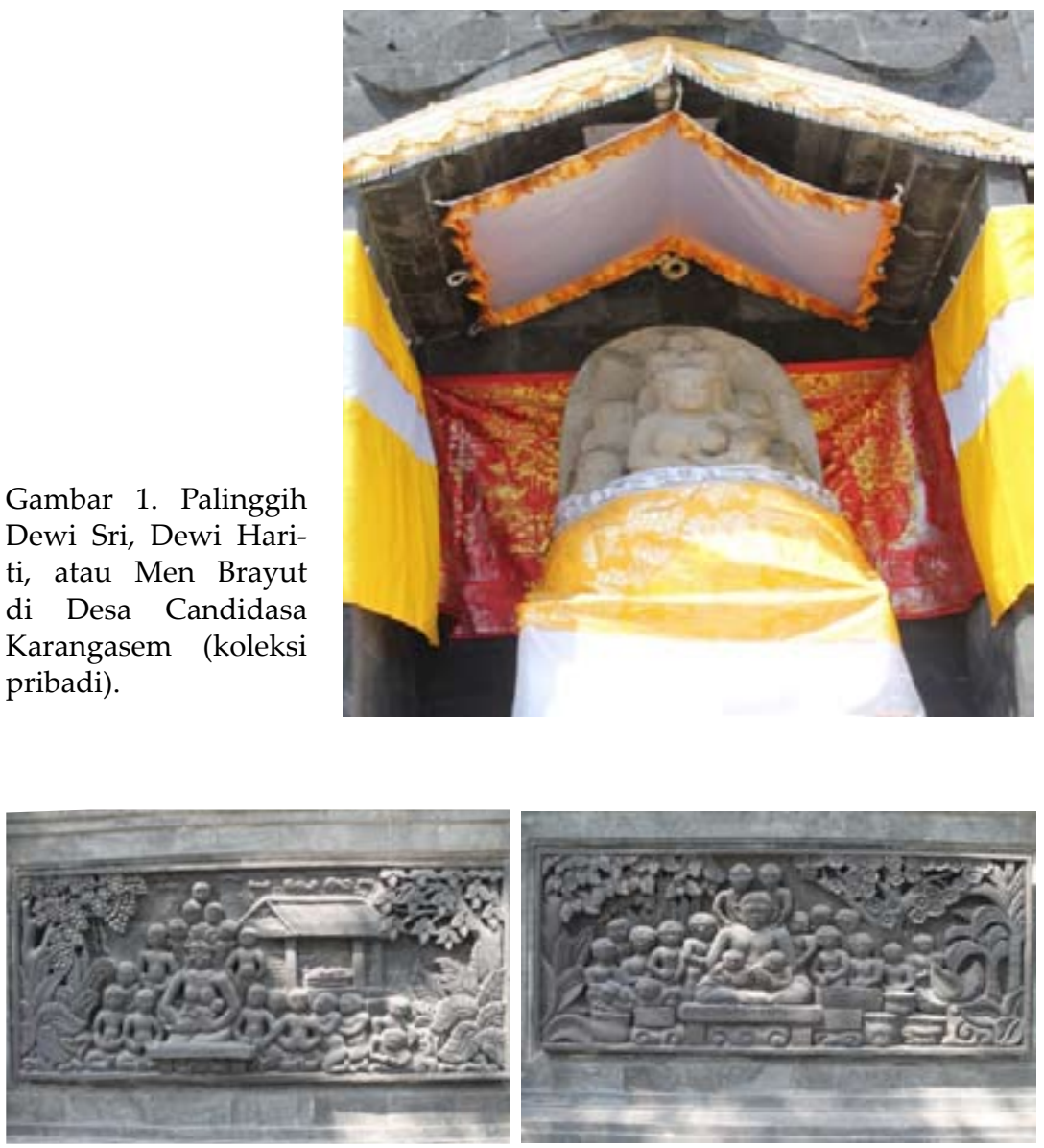

Gambar 2. Relief Keluarga Brayut yang banyak anak sebagai simbol kesuburan di Desa Candidasa Karangasem (koleksi pribadi).

Dari paparan di atas jelas menunjukkan bahwa ideologi pertanian menjadi domain penting pada era tradisional. Di samping itu ideologi keagamaan juga menjadi ranah yang dikontestasikan oleh agama Hindu, Budha, dan kepercayaan lokal melalui tokoh Brayut ini.

Ideologi Tantrisme juga sangat menonjol dalam kisah Brayut. Hal ini tersirat dalam berbagai jenis makanan dan minuman beralkohol yang disajikan pada saat perayaan Galungan dan pesta-pesta keluarga. Jumlah anak yang banyak serta seringnya hubungan intim yang dilakukan secara tersirat menunjukkan Tantrisme dipraktikkan saat itu yang dikenal dengan panca tattwa atau panca ma, yaitu: (1) Matsya makan ikan; (2) Madya, minum minuman keras; (3) Mamsa, makan daging; (4) Mudra, 
gerakan-gerakan tertentu; (5) Maituna, hubungan seks, sebagai media pemujaan. Tujuannya adalah untuk mendapatkan kekuatan, kekuasaan, dan kesaktian (pengetahuan) dari Dewi Parwati sebagai Sakti Siwa (Phalgunadi, 2006:34).

Banyak anak banyak rejeki menjadi ideologi yang berkembang pada masa tradisional pertanian dengan pertimbangan bahwa untuk menggarap sawah dan ladang di era pertanian dibutuhkan tenaga yang cukup banyak, dengan demikian hasil pertanian menjadi semakin berlimpah.

Tahapan-tahapan kehidupan yang dikenal dalam agama Hindu dengan istilah Catur Asrama juga tersurat dan tersirat dalam gaguritan Brayut. Hal ini digambarkan dalam upaya Pan Brayut untuk memperdalam spiritualitasnya setelah anak-anaknya tumbuh dewasa dengan memperdalam ajaran Budha pada Pangeran Jembong yang ahli dalam agama Budha. Setelah kemampuan spiritualnya dipandang cukup, Brayut meninggalkan keluarganya (masa Grehasta) untuk menjadi Bhiksuka dan Wanaprasta dengan mendirikan pasraman di arah timur rumah keluarganya.

Tahapan-tahapan kehidupan yang dilalui keluarga Brayut sepintas memang seperti gambaran secara umum kehidupan keluarga petani. Namun bila dikaji lebih mendalam sebenarnya di sini terdapat sebuah konsep yang disebut catur asrama sebagai tahapantahapan kehidupan yang harus dilalui oleh seorang penganut Hindu. Dengan demikian Brayut memiliki fungsi sebagai tipe ideal bagi keluarga Hindu dalam menjalani kehidupan di dunia ini. Setelah anak-anak tumbuh dewasa dan berumah tangga maka orang tua mestinya mulai meninggalkan hal-hal yang bersifat keduniawian.

Dari fenomena di atas tampak bahwa identitas Brayut rupanya mengalami konstruksi, dekonstruksi, dan rekonstruksi sesuai dengan situasi, dan tentu saja kekuasaan memberikan konstrubusi besar dalam konstruksi identitasnya. Hal ini menegaskan bahwa identitas selalu bersifat cair, dengan kata lain bahwa identitas Brayut merupakan hasil konstruksi diskursif. Jadi, sebuah identitas itu dibangun, diciptakan ketimbang ditemukan (Barker, 2006; Maunati, 2012). Demikianlah Brayut menjadi tokoh yang termarjinalkan di era Orde Baru, namun kini mulai terangkat kembali dan memberi inspirasi baru bagi para pematung.

Ada hal menarik yang kiranya perlu diungkap terkait dengan keluarga Brayut ini, terutama dari aspek religiusitas masyarakat 
Bali yang tersimpan di balik fenomena Brayut sebagai keluarga kumuh, banyak anak, tidak merawat diri, dan lain sebagainya yang memberinya kesan marginal yang dilekatkan padanya oleh masyarakat. Di sisi lain dia memiliki kekuatan yang bersifat religio magis sehingga diyakini mampu membantu masyarakat untuk mendapatkan keturunan.

Bila dicermati secara lebih mendalam terkait dengan kehidupan keluarga Brayut yang tersurat dan tersirat dalam lontar Gaguritan Brayut menunjukkan bahwa Brayut adalah keluarga yang berhasil dalam mendidik anak-anaknya meskipun mereka memiliki anak dalam jumlah yang cukup banyak, yaitu 18. Jumlah ini bila dicermati dalam kaitan dengan sistem religi masyarakat Hindu di Bali adalah angka istimewa karena merupakan kelipatan angka 9. Angka 9 dipandang sebagai angka tertinggi, angka yang diyakini memiliki nilai religiomagis dalam sistem keyakinan masyarakat Hindu di Bali.

Anak-anak yang jumlahnya 18 itu pun memiliki karakter yang berbeda-beda. Brayut berhasil membesarkan anak-anaknya dengan penuh kasih sayang sehingga mereka tumbuh kembang menjadi anak-anak yang memiliki karakter yang kuat. Setelah anak-anak itu tumbuh dewasa Brayut kemudian memutuskan untuk menekuni bidang spiritual dengan berguru pada guru spiritual bernama Jembong seperti kutipan berikut.

De Brayut duke ngayat, manunas bekele mati (bait 60) artinya Brayut ketika melakukan pemujaan memohon bekal mati (bisa dikatakan sebagai ilmu kelepasan)

Dengan demikian dapat dikatakan bahwa Brayut telah menjadi simbol keagamaan yang mendominasi pemikiran masyarakat di era tradisonal pertanian. Penggunaan simbol sebagai alat dominasi sejalan dengan pandangan yang disampaikan oleh Thompson (2015:20) yang menyatakan bahwa studi ideologi dalam bentuk simbol dapat dimanfaatkan sebagai alat untuk membangun dan mempertahankan relasi kekuasaan. Ideologi dalam hal ini adalah bagian integral dari kontestasi yang merupakan ciri kreatif dan konstitutif kehidupan yang dipertahankan dan dikembangkan, dipertaruhkan dan ditransformasikan, melalui aksi dan interaksi yang memasukkan pertukaran bentuk-bentuk simbol.

Dalam perjalanan waktu selanjutnya tokoh Brayutyang semula menjadi simbol yang diperebutkan dengan tujuan dominasi, di era 
Orde Baru Brayut telah bergeser posisinya sebagai simbol yang termarjinalkan dalam kaitan dengan program Keluarga Berencana. Hal ini dinyatakan oleh I Nyoman Darnita di Denpasar sebagai berikut.

"di era Orde Baru begitu mendengar nama Brayut, maka konotasinya pasti jelek. Brayut telah menjadi simbol keluarga kumuh dengan banyak anak sehingga tak sempat mengurus diri dan keluarganya. Tradisi Brayut sebagai tempat memohon anak pada masa sebelumnya, telah berubah di era Orde Baru"

Menurut Giddens (2005: 49) tradisi adalah sebuah orientasi ke masa lalu bahwa masa lalu memiliki pengaruh besar atau secara lebih akurat, tradisi dibuat memiliki pengaruh yang besar pada masa sekarang. Namun jelas dalam arti tertentu, tradisi adalah tentang masa depan, karena praktik-praktik yang telah mapan digunakan sebagai cara mengorganisasi waktu masa depan. Masa depan dibentuk tanpa perlu menganggapnya sebagai wilayah yang terpisah dengan masa lalu. Pengulangan dalam sebuah hal yang perlu diteliti merentang untuk membalikkan masa depan ke masa lalu, di samping mengambil masa lalu untuk merekonstruksi masa depan. Tradisi selalu berubah-ubah, tetapi ada sesuatu tentang gagasan tradisi yang memiliki daya tahan jika bersifat tradisional, sebuah kepercayaan atau praktik yang memiliki integritas dan keberlanjutan, yang menentang desakan perubahan. Maka, integritas dan otentisitas sebuah tradisi memiliki arti lebih penting di dalam mendefinisikan sebuah tradisi dibandingkan dengan lamanya sebuah tradisi dapat bertahan.

Dari paparan tersebut dapat diketahui bahwa tradisi tidak statis, tetapi bersifat aktif serta selalu mengalami reinterpretasi sehingga dapat berubah dari waktu ke waktu. Kebenaran dalam sebuah tradisi bisa berarti sebuah kebenaran yang bersifat cair sesuai dengan konteks zaman. Dapat dikatakan bahwa pemaknaan sosial terhadap objek berasal dari makna yang diberikan padanya melalui interaksi. Interaksi atau dunia sosial didefinisikan sebagai suatu tatanan yang dirembugkan secara temporer; jelasnya ia harus dibangun kembali secara terus-menerus untuk menafsirkan dunia (Coulon, 2008:11). Gayut dengan hal ini Barthes sebagaimana dikutip Trifonas (2003:62) mengatakan bahwa makna-makna itu melayani kepentingan tertentu dari budaya yang berkuasa, yang 
memanfaatkan mitos untuk melakukan reproduksi kultural.

Kekuasaan di era Orde Baru ternyata telah dimanfaatkan untuk kepentingan dominasi untuk mensukseskan program pemerintah berupa Keluarga Berencana. Dua anak cukup demikian slogan yang selalu didengungkan. Maka Brayut yang sebelumnya dalam posisi sebagai Dewi penyayang anak-anak telah berubah posisinya menjadi sangat marginal, akibat doktrin yang disampaikan oleh penguasa saat itu.

Hal ini bisa terjadi karena legenda Brayut ini hanya sepenggal saja yang dimanfaatkan dalam kaitan dengan mensukseskan program Keluarga Berencana yaitu bahwa Brayut adalah tipe keluarga yang tidak patut ditiru karena memiliki banyak anak. Kisah sepenuhnya dari keluarga Brayut jarang bahkan hampir tidak pernah diungkapkan. Jika kisah keluarga Brayut ini dicermati maka jelas bahwa keluarga ini telah berhasil mendidik anakanak mereka dengan suasana demokratis sehingga mereka dapat tumbuh kembang sesuai dengan bakatnya masing-masing. Hal ini tergambar dengan jelas apabila dicermati keseluruhan kisan Brayut yang ditulis dalam bentuk gaguritan. Kekuasaan telah mengambil sebagian kecil dari kisah ini untuk kepentingan dominasi untuk menyampaikan program Keluarga Berencana di era Orde Baru.

Bertitik tolak dari paparan data yang disampaikan pada bagian sebelumnya bahwa ideologi yang melekat pada tokoh Brayut mengalami dinamika dari masa ke masa. Pada masa sebelum Orde Baru, tokoh Brayut digambarkan sebagai simbol kehidupan petani dengan segala dinamikanya. Pada masa tersebut Brayut mewakili ideologi yang berkembang pada masanya. Ideologi yang didukung adalah banyak anak banyak rejeki. Hal ini berdasarkan sistem kerja saat itu, karena anak dianggap aset untuk membentu dalam pengerjaan lahan pertanian. Tiap anak dengan karakternya membawa rejekinya masing-masing. Tahapan-tahapan kehidupan berjalan apa adanya sebagaimana telah digariskan oleh agama yang dianut. Orang tua dalam hal ini Brayut mulai menekuni bidang spiritual manakala anak-anaknya telah tumbuh dewasa.

Penafsiran tentang keluarga Brayut mulai berubah manakala Orde Baru mulai berkuasa di Indonesia. Pemerintah pada waktu itu sangat gencar mensosialisasikan keluarga kecil bahagia melalui Program Keluarga Berencana. Dalam program ini dua anak cukup, laki perempuan sama saja. Demikian program yang 
selalu disampaikan kepada masyarakat. Keluarga Brayut akhirnya menjadi korban ideologi ini. Stigma yang dilekatkan kepadanya adalah keluarga yang tidak mampu mengurus anggotanya karena terlalu banyak anak-anak yang harus dirawat. Dengan demikian Men Brayut menjadi tokoh yang termarjinalkan dengan label yang dilekatkan kepadanya sebagai wanita yang kurang merawat diri dan keluarganya akibat dari banyaknya anak-anak yang harus dirawat dan dibesarkan. Ceritanya dipotong sampai di sana, sehingga bagaimana keberlanjutan keluarga Brayut yang akhirnya mampu menghasilkan anak-anak yang bisa berkembang sesuai dengan bakat, minat dan kompetensi yang dimilikinya seakan tidak pernah dimunculkan kepermukaan.

Di era postmodern saat ini, penafsiran terhadap tokoh Brayut ini pun mengalami reinterpretasi kembali. Kajian-kajian yang muncul malah memberikan posisi lebih terhormat kepada Brayut bila dibandingkan dengan era Orde Baru. Kajian terhadap Brayut justru memberikan nilai tambah kepada tokoh ini karena ternyata dia berhasil mendidik anak-anaknya dengan baik sehingga semuanya tumbuh kembang sesuai dengan bakat, karakter dan potensi yang dimiliki. Muncullah beberapa karya seni patung yang menggunakan tokoh Brayut sebagai modelnya. Men Brayut digambarkan dengan wajah yang ceria, dengan dandanan rambut yang rapi dan senyum manisnya yang menawan. Jumlah anak yang mendampinginya pun jumlahnya tidak sebanyak yang digambarkan sebelumnya.

Sebagai bahan untuk dicermati berikut ini akan ditunjukkan beberapa hasil karya seni yang tercipta mewakili zamannya sebagaimana tergambar pada gambar 3 berikut.

Gambar3. Men Brayut dalam bentuk patung yang kini banyak dipakai sebagai hiasan taman. Digambarkan sebagai wanita cantik dengan telanjang dada sehingga tampak eksotik meskipun anak-anaknya masih dibuat cukup banyak.

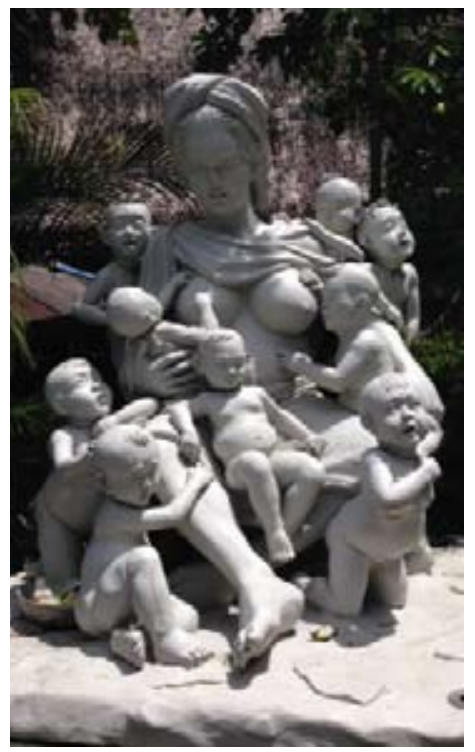



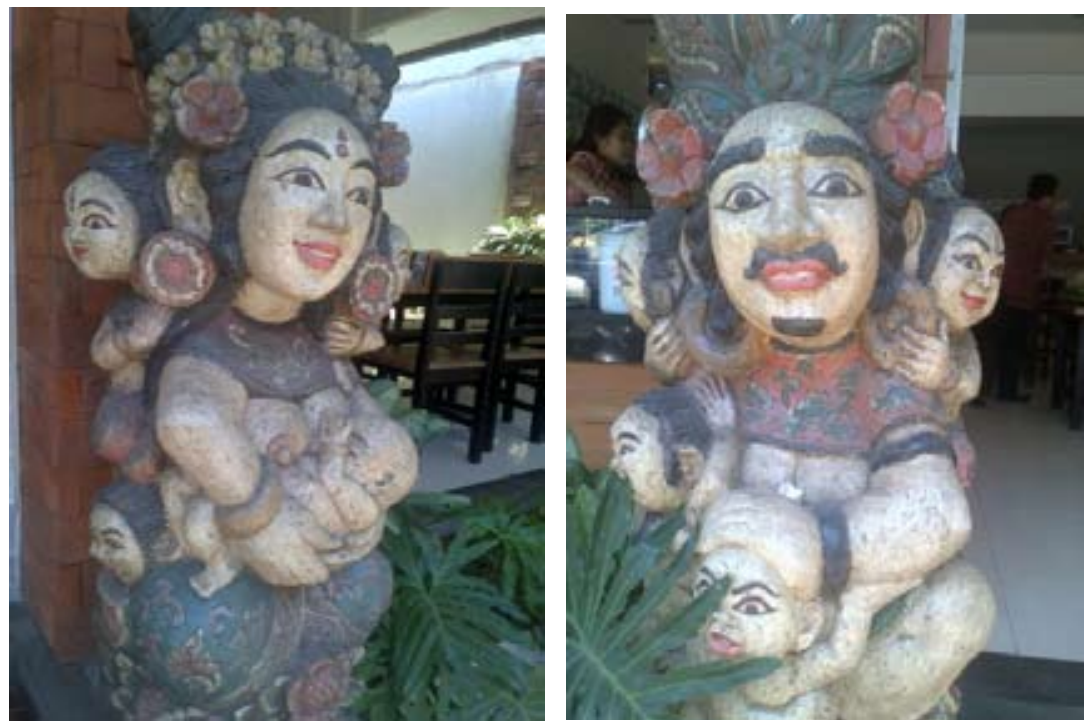

Gambar 4. Patung Keluarga Brayut sebagai hiasan pintu masuk sebuah rumah makan di Denpasar (koleksi pribadi)

Kini kembali muncul tokoh Brayut dalam bentuk patung yang difungsikan seperti penjaga pintu masuk dengan menggunakan atribut-atribut yang sudah disesuaikan dengan kondisi kekinian. Brayut digambarkan membawa hanya empat anak,yang mungkin disesuaikan dengan konsep keluarga di Bali. Jumlah anaknya adalah empat dari Wayan sampai Ketut. Hiasan rambautnya dibuat rapi dengan hiasan senyum yang manis menawan seperti terlihat dalam gambar 4 (terlampir).

Memperhatikan tampilan tokoh Brayut yang terakhir, tidaklah berlebihan bila dikatakan bahwa dia mewakili ideologi yang sedang diwacanakan dalam masyarakat di Bali saat ini yaitu suatu bentuk perlawanan melalui karya seni tentang program Keluarga Berencana yang selama orde baru sangat sukses di Bali. Saat ini Bali dapat dikatakan mencapai sukses besar dalam menekan jumlah kelahiran, sehingga nama Nyoman dan Ketut mulai hilang pada generasi yang lahir di era tahun tujuh puluhan. Namun dalam perkembangan selanjutnya masyarakat Bali mulai melihat bahwa saudara-saudara mereka yang lainnya di Indonesia belum semuanya mau melaksanakan program Keluarga Berencana seperti yang dilakukan di Bali. Ketika booming pariwisata berhasil meningkatkan kesejahteraan masyarakat Bali, hal ini menarik 
masuknya penduduk luar Bali yang jumlahnya semakin banyak. Setelah peristiwa bom Bali, masyarakat Bali mulai mewacanakan Ajeg Bali termasuk keberlanjutan nama-nama seperti Wayan, Made, Nyoman, dan Ketut mulai mencuat kepermukaan. Bila kita mampu apa salahnya jika kita mempunyai anak lebih dari dua? Teman-teman yang lain malah jumlahnya semakin banyak saja yang masuk ke Bali. Jangan-jangan masyarakat hanya menjadi korban kampanye dua anak cukup laki perempuan sama saja. Demikian wacana yang berkembang dalam masyarakat terkait dengan jumlah anak yang harus dimiliki oleh orang Bali.

Saat ini, gaya hidup modern dengan orientasi global hampir menguasai setiap aspek kehidupan manusia Bali. Berbagai etika, tradisi yang mengikat kelompok budaya sebelumnya menjadi goyah didesak oleh gaya hidup baru zaman modern. Gaya hidup modern sering kali dikaitkan dengan rasionalisasi, konsumtivisme, komersialisasi budaya lokal, yang pada ujungnya nanti dipandang akan menghancurkan budaya nasional.

Bila diperhatikan keberadaan tokoh Brayut dalam religi masyarakat Hindu di Bali, kiranya ia terbawa arus gelombang perubahan sebagaimana diungkapkan di atas. Pada era tahun 50an sampai tahun 60-an manakala masyarakat Bali masih bercorak sangat agraris, tokoh Brayut sangat disakralkan. Dia ditempatkan di tempat-tempat yang disakralkan di areal Pura. Seiring berjalannya waktu, maka pada era orde baru di awal tahun 70-an Brayut malah menjadi tokoh marginal dengan stigma keluarga yang tak patut ditiru karena banyak anak.

Saat ini ideologi Brayut masih tetap bertahan meskipun tak luput dari proses penyesuaian dengan perkembangan zaman. Brayut masih tetap dipuja di beberapa tempat untuk memohon keturunan. Di sisi lain ia juga memberi inspirasi bagi penciptaan berbagai karya seni sehingga muncul berbagai bentuk patung Brayut yang menghiasi tempat-tempat yang menajdi objek wisata. Dalam hal ini nampak kapitalisme memberikan motivasi kuat bagi terciptanya berbagai bentuk patung Brayut. Belakangan dijumpai pula bahwa Brayut divisualisasikan sebagai tokoh untuk menyuarakan perlawanan terhadap hegemoni dan dominasi negara seperti Brayut dengan empat anak sesuai dengan konsep jumlah anak keluarga Bali.

Dalam sebuah artikelnya Fukuyama dengan penuh percaya diri 
mengemukakan bahwa pasca perang dingin dimana kapitalisme dan demokrasi liberal menjadi pemenangnya, ini merupakan puncak dan akhir peradaban dunia atau dengan kata lain sejarah telah berakhir. Tetapi akhir sejarah lebih dimaknai bahwa tidak akan ada kemajuan penting lebih lanjut dalam perkembangan yang mendasari prinsip-prinsip dan institusi-institusi, karena seluruh persoalan besar yang sesungguhnya telah terjawab (Ma'ruf, 2003)

Apa yang disampaikan oleh Fukuyama mendapat tanggapan dari Samuel P. Huntington yang lebih menekankan bahwa peradaban sekarang lebih menuju pada pluralisme dari pada universalisme. Karena itu menurut Huntington, sumber fundamental dari konflik dalam dunia baru ini pada dasarnya tidak lagi ideologi atau ekonomi, melainkan budaya. Budaya akan memilah-milah manusia dan menjadi sumber konflik yang dominan (Huntington, 2003).

Di sisi lain para penganut paham postmodern berpendapat bahwa kontak budaya tidak mungkin dihindari di era global, sehingga akan terjadi pengaruh timbal balik dengan cara yang mendalam, sehingga terjadi fenomena yang disebut glokalisasi (globalisasi dan lokalisasi) budaya, dimana unsur lokal dan global saling bertukar dan dapat hidup bercampur menjadi satu. Di sini nampak bahwa penganut paham postmodern menolak adanya proyek-proyek global yang membawa sifat universalisme, tetapi ingin melihat, menghargai perbedaan, keunikan, sejarah dari bagian-bagian dunia ( Parimartha, 2003)

Yang perlu dicatat dari kedua paham tersebut baik paham modern maupun postmodern adalah, akan selalu terjadi proses dialektika budaya dalam masyarakat (termasuk Bali). Oleh karena itu yang menjadi problem saat ini adalah bagaimana membuat manusia Bali memiliki ketahanan budaya dalam menghadapi budaya asing sehingga mereka tidak tercabut dari akar budayanya, karena menghindarkan diri dari pergaulan budaya globa sudah tidak mungkin. Oleh karena itu, akan tergantung pada responrespon dari budaya lokal terhadap pengaruh budaya Barat yang telah begitu kuat pengaruhnya di dunia.

Brayut pun tak terhindarkan dari proses komodifikasi. Komodifikasi menurut Barker (2005) adalah proses yang diasosiasikan dengan kapitalisme, di mana benda-benda, kualitas, dan tanda-tanda diubah menjadi komoditas. Fenomena 
ini terlihat dari semakin banyaknya patung-patung Brayut yang diperdagangankan di daerah sekitar Jalan Bypass Prof Dr Ida Bagus Mantra.

Kecenderungan ini menurut Nashir (1999) terjadi karena proses rasionalisasi yang menyertai modernitas telah menciptakan sekularisasi kesadaran dan memperlemah fungsi kanopi suci agama dari domain kehidupan para pemeluknya sehingga menimbulkan ketidakberartian pada diri manusia modern. Hal-hal sakral yang berfungsi sebagai faktor sublimasi dan penguatan eksistensi manusia, digantikan oleh hal-hal yang serba rasional sehingga terjadilah dekonstruksi transendensi kognisi manusia atau dengan istilah sekularisasi alam bathin.

Sementara itu Halim (2002) berpandangan bahwa munculnya variasi estetis adalah penegasan terjadinya desakralisasi agama. Ketidakberdayaan pengukuhan sosial yang umum dan tetap, definisi-definisi agama tentang realitas telah kehilangan sifat kepastian. Iman kepercayaan tidak lagi tersedia secara sosial, tetapi diperoleh sendiri secara individual. Individu menjadi unsur yang lebihotonom dalam praktik-praktikkeagamaankarenamelemahnya kewibawaan institusi agama. Seluruh segi kehidupan manusia kini hampir tidak memiliki daya tolak terhadap hegemoni kapitalisme global. Kapitalisme global secara evolutif telah menggeser nilainilai sakral dalam ajaran agama dan tradisi, sehingga menjadi instrument bagi pembentukan gaya hidup yang berorientasi pada kesenangan dan kepuasan. Konsep-konsep kehidupan yang telah mapan dikaji ulang dan disesuaikan dengan standar nilai yang diciptakan oleh kapitalisme. Agama secara perlahan-lahan digeser dari kedudukannya sebagai sumber nilai dalam pembentukan hidup itu sendiri. Kehidupan keagamaan telah ditarik dari wilayah sakral menuju pola kompetisi yang bersifat profan.

Petaka kehidupan manusia modern menurut Nashir (1999) sebenarnya berawal dari adanya perubahan dari ideologi yang bersifat theosentris menuju humanism-antroposentris. Gejala ini muncul di Eropa ketika bangsa-bangsa di wilayah ini memasuki era Renaissance (Pencerahan) yang muncul sekitar abad ke-16 yang kemudian diikuti oleh Revolusi Industri pada abad ke-18. Alam pikiran Pencerahan ini bertumpu pada nilai-nilai utama kemanusiaan (humanism) seperti individualism, kebebasan, persaudaraan, dan kesamaan yang berkiblat pada manusia 
(antroposentris). Humanisme-antroposentris menempatkan manusia sebagai pusat segala-galanya, sebagai lawan dari dn mengganti alam pikiran teosentrisme (alam pikiran yang sematamata pada ketuhanan dari agama Kristen dan FilsafatSkolastik)yang mendominasi alam pikiran Abad Pertengahan dalam kebudayaan Barat yang saat itu dipandang membelenggu kebebasan manusia. Sejak zaman Renaisans itulah humanism-antroposentris menjadi semacam agama baru dalam kebudayaan modern, yang menyebar dan diadopsi hampir oleh segenap bangsa di negeri-negeri lain di luar Eropa Barat.

Secara sosiologis Bungin (2007), berpandangan bahwa masyarakat memulai kehidupan mereka pada suatu fase yang disebut primitif, dimana manusia hidup terisolir dan berpindahpindah disesuaikan dengan lingkungan alam dan sumber makanan yang tersedia. Mereka hidup dalam kelompok-kelompok kecil. Fase berikutnya adalah fase agrokultural, ketika lingkungan alam sudah tidak lagi mampu memberikan dukungan terhadap manusia, termasuk juga karena populasinya sudah mulai banyak. Fase tradisional dijalani oleh masyarakat dengan hidup secara menetap di suatu tempat yang dianggap representatif. Pada tahap ini mulai dikenal "desa" sebagai tempat penduduk berinteraksi. Perkembangan selanjutnya adalah fase transisi, kehidupan masyarakat sudah sangat maju, isolasi kehidupan hampir sudah tidak ditemukan lagi dalam skala luas, transportasi dan komunikasi sudah sangat lancar. Namun secara geografis msyarakat transisi biasanya berada di pinggiran kota, serta hidup mereka masih secara tradisional, termasuk pola pikir dan sistem sosial lama masih silih berganti digunakan dan mengalami penyesuaian dengan hal-hal baru dan inovatif. Dengan demikian, maka umumnya masyarakat transisi bersifat mendua atau ambigu terhadap sikap, pandangan, dan perilaku mereka sehari-hari. Pola pikir masyarakat masih tradisional dan masih memelihara kekerabatan namun perilaku masyarakat sudah terlihat individualis. Sesuatu yang masih dominan dalam kehidupan masyarakat adalah proses asimilasi budaya dan sosial yang belum tuntas dan masih canggung di semua level msyarakat. Lama kelamaan masyarakat berkembang dan masuk dalam fase modern yang ditandai denga peningkatan kualitas perubahan sosial yang lebih jelas meninggalkan fase transisi. Kehidupan masyarakat sudah kosmopolitan dengan 
kehidupan individual yang sangat menonjol, profesionalisme di segala bidang dan penghargaan terhadap profesi menjadi kunci hubungan-hubungan sosial di antara elemen masyarakat. Sekulerisme menjadi sangat dominan dalam kehidupan religi masyarakat, dan kontrol sosial serta sistem kekerabatan menjadi sangat longgar. Perkembangan lebih lanjut mengantarkan masyarakat pada fase postmodern. Menurut para pengamat fase ini terdeteksi di Indonesia pada sekitar tahun 1990-an.

Sementara itu dalam pengamatan Raharjo (2004), perubahan masyarakat dari satu fase ke fase berikutnya disebabkan oleh beberapa faktor sebagai berikut.

Masuknya sistem ekonomi uang, tidak saja mengakibatkan berkurangnya ketergantungan masyarakat desa pada sektor pertanian, melainkan juga mengubah orientasi produksi para petaninya. Perubahan orientasi itu adalah dari produksi yang semula sekadar ditujukan untuk memenuhi kebutuhan keluarga berubah menjadi demi keuntungan (profit oriented). Komunikasi model pasar dengan demikian tidak dapat dihindari sehingga hampir seluruh sistem sosial masyarakat dibangun atas model jual-beli.

Perubahangayahidup. Gayahidup masyarakatdesa tradisional yang terbiasa dengan serba bersahaja mulai berubah menuju gaya hidup orang kota yang modern. Sifat dan ragam kebutuhan orang desa semakin meningkat. Akibat kebutuhan hidup yang semakin meningkat inilah mendorong para petani untuk mengarahkan produksi pertaniannya untuk mengejar uang. Ini berarti keluarga tidak merumuskan sendiri berbagai kebutuhannya, melainkan media telah memaksa mereka membuat pilihan akan kebutuhan yang pada dasarnya sering tidak fungsional dalam kehidupan mereka.

Terjadinya urbanisasi. Urbanisasi selain berarti terjadinya pergeseran penduduk dari desa ke kota (urbanward migration), juga mengandung pengertian (1) proses pengkotaan (proses mengkotanya suatu daerah/desa) juga berarti (2) proporsi penduduk yang tinggal di kota dibanding dengan yang tinggal di desa. Urbanisasi dalam pengertian pertama dan kedua masih dipandang sebagai hal yang positif, namun bila pengertian yang dimaksud adalah perpindahan penduduk dari desa ke kota maka akan memunculkan beberapa kerugian dari pihak desa. Urbanisasi 
mengakibatkan desa-desa kehilangan tenaga-tenaga terbaik (kaum muda) dan terpandainya. Kebanyakan mereka yang berurbanisasi adalah golongan muda. Golongan muda yang pergi ke kota itu adalah (1) yang memiliki kecakapan terbaik, dan (2) yang memiliki kecakapan terendah. Golongan muda yang memiliki kecakapan menengah umumnya tetap tinggal di desa.

Perubahan dalam masyarakat dan kebudayaan terjalin berkelindan. Menurut Francis (2006) kebudayaan tidak bersifat statis, namun bersifat mengalir, senantiasa bergerak dan berubah. Jarak dan langkah dari perubahan kultural berskala luas bisa beraneka ragam dari satu masyarakat dengan masyarakat yang lainnya, namun bahkan dalam masyarakat yang paling tradisonal sekalipun tetap akan terjadi sebuah perubahan, kendati berskala kecil dan hampir tidak terlihat, karena manusia bukan sekadar fungsi dari kebudayaan mereka, namun juga pelaku yang dapat menentukan pilihan. Sebagai balasannya manusia terbentuk dari kebudayaan dan membentuk kebudayaan, keduanya bersifat abadi dan senantiasa berubah.

Dalam budaya tradisional, masa lalu dihormati dan simbol dihargai karena mereka berisi dan bertanggung jawab atas pengalaman berbagai generasi. Tradisi adalah cara untuk mengintegrasikan monitoring tindakan secara refleksif dengan penataan ruang-waktu dalam komunitas. Ini adalah sarana untuk menangani ruang dan waktu, yang memasukkan segala aktivitas atau pengalaman tertentu di dalam keberlanjutan masa lalu, masa kini dan masa depan, yang pada gilirannya distrukturkan oleh praktik-praktik sosial yang tengah berlangsung. Tradisi tidak sepenuhnya statis, karena ia harus ditemukan ulang oleh setiap generasi baru ketika ia mengambil alih warisan budaya dari pendahulunya. Tradisi tidak terlalu melawan perubahan ketika terjadi dalam konteks di mana ada beberapa pertanda temporal dan spasial yang terpisah dengan catatan perubahan itu bisa memiliki bentuk yang bermakna (Gidden, 2005).

Persoalan yang perlu mendapat perhatian dalam hal ini adalah apa yang dapat ditawarkan oleh agama agar eksistensinya tetap terjaga di tengah-tengah perubahan yang terjadi dalam masyarakat. Menurut Hidayat (2003) bahwa agama hendaknya mampu mentransendensikan diri, berada di atas pluralitas budaya dan bangsa, lalu memberikan visi, motivasi, dan pencerahan kemanusiaan 
dalam bingkai kebangsaan dan kebudayaan. Gerakan keagamaan pada akhirnya adalah gerakan kebudayaan karena manifestasi akhir dan perilaku seseorang tampil dalam ranah budaya. Jikalau sebuah agama tidak mampu mengartikulasikan diri dalam wadah budaya sebagai gerakan emansipatoris, maka agama akan ditinggalkan orang. Sebaliknya, gerakan kebudayaan yang tidak memiliki dimensi transenden juga tidak akan mampu memperoleh dukungan abadi dan militan. Dalam pada itu, agama apapun pada akhirnya akan diuji oleh sejarah dengan ukuran-ukuran kemanusiaan secara empiris. Dengan singkat dapat dikatakan bahwa agama sebaiknya melakukan reinterpretasi terhadap dogma-dogmanya sehingga selalu aktual dengan zamannya.

Dengan demikian semakin tampak bahwa agama memang diperlukan dalam menata perilaku manusia, baik pada tataran individual maupun sosial. Agama bukan hanya sebuah dogma dan ibadat yang tenggelam dan mati di dasar kognitif manusia, melainkan pedoman praktis dalam menjalankan kehidupan pribadi dan sosial. Agama fungsional dalam keseluruhan kehidupan manusia yang mampu menjawab dan mengatasi segala persoalan yang dihadapi manusia, baik dalam hubungan pribadinya dengan Tuhan, dengan sesama, dan dengan alam. Hal ini menjadi penting karena pengalaman manusia yang diperoleh dari ketidakpastian, ketidakberdayaan, dan kelangkaan yang memang merupakan karakteristik fundamental kondisi manusia. Dalam hal ini fungsi agama adalah menyediakan dua hal. Pertama, memberikan suatu cakrawala pandang tentang dunia luar yang tidak terjangkau oleh manusia, dalam arti di mana deprivasi dan frustasi dapat dialami sebagai sesuatu yang mempunyai makna. Kedua, menyediakan sarana ritual yang memungkinkan hubungan manusia dengan hal di luar jangkauannya, yang memberikan jaminan dan keselamatan bagi manusia mempertahankan moralnya (O’Dea, 1985).

Dari paparan di atas kiranya dapat dipahami bahwa Brayut sebagai sebuah simbol ideologi masih tetap bertahan hingga saat ini karena di dalamnya terkandung nilai-nilai agama yang memang dekat dengan kondisi masyarakat pendukungnya sehingga dia bersifat elastis dalam menyikapi perkembangan yang terjadi.

Seturut dengan pandangan Gidden (2004) bahwa cara hidup yang dimunculkan oleh modernitas telah membersihkan masyarakat dari semua tatanan sosial tradisional, dengan cara yang 
tidak pernah ada sebelumnya. Namun demikian dalam situasi ini sebenarnya ada kontinyuitas antara kehidupan tradisional dengan kehidupan modern, dan tidak semuanya terputus sama sekali. Sementara itu menurut Duverger (2005), di dalam suatu masyarakat di mana ada konsensus tentang masalah legitimasi, tidak akan menimbulkan gejolak dalam masyarakat. Akan tetapi sebaliknya, bilamana ada ketidaksetujuan tentang legitimasi, kesulitan tak terelakkan akan timbul.

Akan tetapi ketika agama mengaktualisasi dalam kehidupan para pemeluknya maka keberagamaan terintegrasi ke dalam sistem nilai sosial budaya, dan wujud kebudayaan fisik yang kemudian bersentuhan melalui proses sosial dengan elemen-elemen sosial budaya lainnya. Secara sosiologis agama dalam realitas kehidupan akan bersentuhan pula dengan pemenuhan kebutuhan hidup manusia, baik yang bersifat fisik-biologis, sosial, ekonomi, dan politik, maupun kebutuhan-kebutuhan integratif yang menyangkut hal-hal yang sangat penting dalam kehidupan manusia, yaitu keinginan untuk hidup beradab, bermoral, tenteram, dan damai.

Dengan demikian dapat dikatakan bahwa keberagamaan itu saling terkait antara hal-hal yang bersifat normatif dengan dimensi kehidupan yang bersifat praksis aktual, baik pada level individual maupun kolektif. Agama dalam hal ini memiliki posisi sentral terutama berkaitan dengan pembentukan nilai-nilai dan normanorma sosial yang dalam praktiknya tidak jarang ditemukan saling berbenturan antara yang satu dengan yang lain. Agama diharapkan mampu menjadi pendamai dalam paradoksal kehidupan nilai dan norma dalam tataran yang paling sublim karena selain agama, manusia tidak lagi memiliki keyakinan tempat menyandarkan nilai kehidupan yang terakhir.

Secara garis besarnya terdapat tiga perspektif dalam memandang hubungan antara agama dengan persoalanpersoalan kemasyarakatan. Pertama, perspektif mekanik holistik, yang memposisikan hubungan antara agama dan persoalanpersoalan kemasyarakatan sebagai sesuatu yang tidak terpisahkan. Kedua, pemikiran yang mengajukan preposisi bahwa keduanya merupakan wilayah-wilayah (domains) yang antara satu dengan lainnya berbeda, karenanya harus dipisahkan. Ketiga, pandangan tengah yang mencoba mengintegrasikan pandangan-pandangan yang antagonistik dalam melihat hubungan agama dan persoalan 
kemasyarakatan.Dipihaklain, pandanganinijugainginmelunakkan perspektif mekanik-holistik yang seringkali melakukan generalisasi bahwa agama selalu mempunyai kaitan atau hubungan yang tidak terpisahkan dengan masalah-masalah kemasyarakatan. Dengan kata lain perspektif yang ketiga ini berpandangan bahwa agama dan persoalan-persoalan kemasyarakatan merupakan wilayah yang berbeda. Namun demikian karena imbasan nilai-nilai keagamaan dalam persoalan-persoalan kemasyarakatan dapat terwujud dalam bentuk yang tidak mekanik-holistik dan institusional, dalam realitas sulit ditemukan bukti-bukti yang tegas (brutefacts) bahwa antara keduanya tidak ada hubungan sama sekali. Untuk itu, hubungan antara dua wilayah yang berbeda itu akan selalu ada walaupun dalam kadar dan intensitas yang tidak sama serta dalam pola dan bentuk yang tidak selalu mekanistik, formalistik atau legalistik. Seringkali konstruksi polanya mengambil bentuk inspiratif dan substantif (Effendy,2001).

Globalisasi telah menimbulkan semakin tingginya intensitas pergulatan antara nilai-nilai budaya lokal dan global. Sistem nilai lokal yang selama ini digunakan sebagai acuan polalaku tidakjarang mengalami transformasi. Proses globalisasi juga telah merambah wilayah kehidupan agama yang serba sakral menjadi sekuler, dapat menimbulkan ketegangan bagi umat beragama. Modernisasi pada level tertentu sesungguhnya menyebabkan merosotnya agama, baik dalam ranah masyarakat maupun ranah individu. Beberapa institusi keagamaan telah kehilangan kekuatan dan pengaruhnya dalam berbagai masyarakat, namun demikian baik keyakinan dan praktek-praktek keagamaan lama maupun baru terus berkembang dalam kehidupan individu, kadang membentuk suatu institusi baru serta mendorong begitu semaraknya semangat keagamaan. Dengan demikian modernisasi yang melahirkan masyarakat yang sangat beragam dan lonjakan quantum dalam komunikasi interkultural, dua faktor yang mendorong munculnya pluralisme dan bukan tegaknya (atau penegakan kembali) monopoli agama (Berger, 2003).

Dengan kata lain bahwa saat ini sudah bukan zamannya lagi bagi adanya pengakuan kebenaran mutlak oleh satu agama tertentu sehingga menisbikan kebenaran-kebenaran lainnya. Turner (2003) yang mengutip pandangan Durkheim menyatakan bahwa agama hanya bisa dipahami dengan melihat peran sosial 
yang dimainkannya dalam menyatukan komunitas masyarakat. Ini mengandaikan bahwa agama bukan hanya berada dalam wilayah sakral yang hanya berbicara tentang Tuhan dan kehidupan setelah kematian. Melainkan juga agama berusuran dengan kehidupan manusia dalam ranah sosial yang secara langsung bersentuhan dengan kebutuhan dan kepentingan mansia dalam melanjutkan eksistensinya. Agama sungguh-sungguh berbicara mengenai pengalaman manusia sesuai dengan hubungan-hubungan berdasarkan emosi sosial yang sarat dengan kontradiksi nilai dan norma. Dengan kata lain bahwa pendidikan agama secara fungsional harus bisa mempersatukan masyarakat dari berbagai latar sosial dan budaya. Hal ini akan tercapai bila tumbuh kesadaran bahwa agama merupakan fenomena budaya yang otonom yang tidak bisa direduksi menjadi hanya sebatas kepentingan ekonomi dan tuntutan politis dalam masyarakat multikultur.

John Stuart Mills, mengingatkan bahwa manusia merupakan makhluk sosial sekaligus intelektual, dan bahwa sebagian besar dari kebahagiaanya tergantung pada pemuasaan atas hasrathasrat sosialnya serta perasaan-perasaanya terhadap hal-hal lain ( Aiken, 2009). Ada tersirat keinginan untuk mengubah situasi dan kondisi dirinya dan lingkungannya setelah melihat stimulusstimulus dari lingkungan sekitarnya. Manusia sebagai makhluk ciptaan Tuhan memiliki struktur dan fungsi yang sangat sempurna bila dibandingkan dengan makhluk ciptaan Tuhan lainnya, karena manusia memiliki tri pramana (bayu, sabda, idep), binatang memiliki bayu dan sabda, sedangkan jenis tanaman hanya memiliki bayu saja. Kelebihan yang dimiliki oleh manusia adalah kemampuannya untuk berpikir (idep). Manusia juga diciptakan sebagai makhluk multidimensional, mempunyai akal pikiran dan kemampuan berinteraksi secara personal maupun sosial. Dengan demikian manusia dipandang sebagai makhluk yang unik, yang memiliki kemampuan sosial sebagai makhluk individu dan makhluk sosial. Di samping itu, dengan kemampuan akal pikirannya manusia mampu mengembangkan kemampuan tertingginya sebagai makhluk ciptaan Tuhan yaitu memiliki kemampuan spiritual, sehingga manusia di samping sebagai makhluk individual, makhluk sosial, juga sebagai makhluk spiritual.

Dalam kenyataannya kemampuan fungsional manusia tersebut dapat dilakukan secara simultan dalam kehidupan sehari-hari 
sebagai makhluk individu, makhluk sosial, dan sebagai makhluk spiritual.Dengan kecerdasannya pula manusiamampumemisahkan fungsi-fungsi dimaksud berdasarkan pada kepentingan dan kebutuhan serta kondisi sosial yang mengitarinya.

Oleh karena manusia adalah makhluk sosial, maka menurut Bungin (2007) manusia pada dasarnya tidak mampu hidup sendiri dalam dunia ini, baik sendiri dalam konteks fisik maupun dalam konteks sosial budaya. Terutama dalam konteks sosial budaya manusia membutuhkan manusia lain untuk saling bekerjasama dalam pemenuhan kebutuhan fungsi-fungsi sosial satu dengan lainnya. Pada dasarnya suatu fungsi yang dimiliki oleh manusia satu akan sangat berguna dan bermanfaat bagi manusia lainnya, karena fungsi-fungsi sosial yang diciptakan oleh manusia ditujukan untuk saling berkolaborasi dengan sesama fungsi sosial manusia lainnya, dengan kata lain manusia akan sangat bermartabat apabila bermanfaat bagi manusia lainnya. Artinya, manusia akan hidup normal, bila menjalankan kehidupannya bersama-sama dengan manusia lainnya. Fungsi-fungsi sosial manusia lahir dari kebutuhan akan fungsi tersebut oleh orang lain, dengan demikian produktivitas fungsional dikendalikan oleh berbagai macam kebutuhan manusia. Setiap manusia memiliki kebutuhannya masing-masing secara individual maupun sosial, dan untuk memenuhi kebutuhan-kebutuhan tersebut perlu adanya perilaku selaras yang dapat diadaptasi oleh masing-masing manusia. Penyelarasan dan penyesuaian kebutuhan individu, kelompok, dan kebutuhan sosial keagamaan manusia yang satu dengan lainnya, menjadi konsentrasi utama pemikiran manusia dalam masyarakatnya yang beradab.

\section{Penutup}

Pada era tradisional Brayut dikenal dengan ideologi pertanian bahwa banyak anak adalah banyak rejeki karena pertanian tradisional membutuhkan banyak tenaga kerja. Di lihat dari setting cerita yaitu Galungan, rupanya pada era tradisional Brayut dipandang memberikan rujukan bagi pelaksanaan ritual keagamaan. Demikian pula tahapan kehidupan yang dilakukan tampak bahwa agama menjadi rujukan perilaku.

Sementara itu di era orde baru, ideology yang dikembangkan oleh penguasa saat itu dengan Program Keluarga Berencana, telah 
memarginalkan posisi Brayut. Saat ini di era postmodern terjadilah kapitalisasi dan komodifikasi tokoh Brayut dalam bentuk patung yang diperjualbelikan.

Berdasarkan paparan di atas kiranya dapat dipahami mengapa ideologi Brayut masih tetap bertahan hingga saat ini dan akan selalu mengalami pembacaan ulang sesuai dengan kebutuhan zamannya, karena ia dihadirkan sesuai dengan konteks zamannya.

\section{Daftar Bacaan}

Aiken, Henry D. 2009. Abad Ideologi. Jogjakarta: AR-RUZZ

Bakker, SJJJ.W.M. 1984. Filsafat Kebudayaan, Sebuah Pengantar. Yogyakarta: Yayasan Kanisius dan BPK Gunung Mulia.

Barker, Chris. 2005. Cultural Studies, Teori dan Praktik. Yogyakarta: Bentang.

Berger, Peter L. 2003. Kebangkitan Agama Menantang Politik Dunia. Yogyakarta: Arruzz.

Bungin, Burhan. 2007. Sosiologi Komunikasi. Teori, Paradigma, dan Diskursus Teknologi Komunikasi di Masyarakat. Jakarta: Kencana Prenada Media Group.

Coulon, Alain. 2008. Etnometodologi. Yogyakarta : LENGGE (Kelompok GENTA PRESS)

Duverger, Maurice. 2005. Sosiologi Politik. Jakarta : Kerjasama Yayasan Ilmu-Ilmu Sosial dengan PT. Raja Grafindo Persada.

Effendi, Bahtiar. 2001. Masyarakat Agama dan Pluralisme Keagamaan, Perbincangan Mengenai Islam, Masyarakat Madani, dan Etos Kewirausahaan. Yogyakarta: Galang Printika.

Francis, Diana. 2006. Teori Dasar Transformasi Konflik Sosial. Yogyakarta: Quills.

Gidden,Anthony, Daniel Bell, dan Michel Forse. 2004. Sosiologi Sejarah dan Berbagai Pemikirannya. Yogyakarta : Kreasi Wacana.

Gidden, Antony, dkk. 2005. Konsekuensi-Konsekuensi Modernitas. Yogyakarta: Kreasi Wacana.

Hidayat, Komaruddin dan Nafis, Muhamad Wahyudi.2003. Agama Masa Depan, Perspektif Filsafat Perenial. Jakarta, PT. Gramedia Pustaka Utama.

Huntington, Samuel P. 2003. Konflik Peradaban Paradigma Dunia 
Pasca Perang Dingin terjemahan dari The Clash of Civilizations: Paradigms of the Post-Cold War World oleh Ahmad Faridl Ma'ruf. Yogyakarta: IRCiSoD.

Nashir, Haedar. 1999. Agama EKrisis Kemanusiaan Modern. Yogyakarta: Pustaka Pelajar.

O'Dea, Thomas F. 1985. Sosiologi Agama. Jakarta: CV. Rajawali.

Parimartha, I Gde. 2003. Pemahaman Lintas Budaya Nusantara dan Internasional, dalam Sarathi Vol 10, No.1 Februari 2003.

Radhakrishnan. R. 2003. Agama-Agama Timur dan Pemikiran Barat. Denpasar: Program Magister Ilmu Agama dan Kebudayaan Universitas Hindu Indonesia bekerja sama dengan penerbit Widya Dharma.

Raharjo. 2004. Pengantar Sosiologi Pedesaan dan Pertanian. Yogyakarta; Gadjar Mada University Press.

Soekartiningsih dan Ni Luh Nirtawati. 2000. Tinjauan Sejarah Serta Hakikat Simbol Kesuburan. Jakarta: Departemen Pendidikan Nasional Direktorat Jenderal Kebudayaan, Bagian Proyek Pembinaan Permuseuman Bali.

Thompson, Jhon B. 2015. Kritik Ideologi Global: Teori Sosial Kritis Tentang Relasi Ideologi dan Komunikasi Massa. Jogjakarta: IRCiSoD

Trifonas, Peter Pericles. 2003. Barthes dan Imperium Tanda. Yogyakarta: Jendela.

Turner, Bryan S. 2003. Agama dan Teori Sosial. Yogyakarta : IRCiSoD.

Utama, I Wayan Budi. 2015. "Brayut dan Lokalisasi Tantrayana di Bali" dalam Ragam Wacana, Sastra, dan Budaya, Kumpulan Tulisan dalam Rangka Purnabakti Prof. Dr. Nyoman Kutha Ratna,SU. Jogjakarta : Pustaka Pelajar.

Worsley, Peter.2015. The Games Painters Paly: Visual Design and Meaning in Balinese Paintings of The Brayut Story from Kamasan Bali, International Seminar on Religious Manuscripts in Multiculturalism for a Better Life (Humanity and Peace), Sept 4th-5th 2015, Institut Hindu Dharma Negeri Denpasar. 